\title{
Does the Disclosure of a Valuation Allowance Reinforce Misguided Incentives of a Progressive Capitalization of Deferred Taxes from Loss Carryforwards?
}

\author{
Andreas Haaker ${ }^{1}$ and Alexander Bull ${ }^{2}$ \\ ${ }^{1}$ DGRV - The German Cooperative and Raiffeisen Confederation Association, \\ Berlin, University of Hagen, Germany \\ ${ }^{2}$ German Institute of Directors (IoD), Munich, University of Hagen, Germany
}

\begin{abstract}
This paper analyzes the incentive problems of the disclosure of a so-called valuation allowance of deferred taxes. Since the disclosure of a relatively high valuation allowance indicates a negative profit development, misguided incentives of a progressive capitalization of deferred taxes from loss carryforwards would have to occur in order to avoid a negative signal. As a result, this would especially increase the loss potential in times of crisis, which would probably lead to a failure of the company.
\end{abstract}

Keywords: Valuation Allowance, Deferred Taxes, Loss Carryforwards, Misguided Incentives.

\section{Introduction}

Recent literature has advocated the implementation of a so-called valuation allowance for deferred tax assets (see Chludek/Tran, 2012, p. 4; IASB, 2009, marginal no. 23 and B16-B25). The capitalization of deferred taxes from loss carryforwards is particularly relevant in the context of international convergence efforts of the standard setters IASB and FASB, as a part of the reform measures for the reporting of deferred taxes according to methods discussed in IAS 12. The disclosure of a valuation allowance could reinforce the existing (misguided) incentives in this precarious field of accounting to such an extent that the mere avoidance of loss or the fulfillment of earnings expectations for a progressive capitalization of deferred taxes from loss carryforwards would not suffice (see Haaker, 2012a; for the influence on big bath accounting see Christensen, Paik and Stice, 2008).

This paper analyzes the incentive problems of the disclosure of a valuation allowance of deferred taxes. The discussions of the 'quality of information' of a value allowance in Section 2 and the 'risk potential' of the capitalization of deferred taxes from loss carryforwards in Section 3 lay the fundament for the justification of misguided incentives in Section 4. Section 5 summarizes the main findings.

Valuation Allowance with Deferred Tax Assets on Loss Carryforwards: Quantity Instead of Quality of Information

One general problem with the capitalization of deferred taxes on loss carryforwards is

Copyright (C) 2012 Andreas Haaker and Alexander Bull. This is an open access article distributed under the Creative Commons Attribution License unported 3.0, which permits unrestricted use, distribution, and reproduction in any medium, provided that original work is properly cited. Contact author: Andreas Haaker E-mail: andreas.haaker@FernUni-Hagen.de 
that, on the one hand, these can only be recoverable if tax profits are generated and no future tax losses are expected, as profits can reduce taxable loss carryforwards. On the other hand, generated taxable losses have been the root cause of the existence of such supposed potential benefits (Schildbach, 1998, p. 945). The view that a trend reversal to a phase of profits is a necessary precondition following a phase of losses as the root cause of loss carryforwards should be considered implausible (Hoffmann and Lüdenbach, 2012, marginal no. 38; Berger, 2006, p. 2474). Loss carryforwards, therefore, can only be capitalized insofar as the offsetting of future losses with high tax revenues is sufficiently probable (IAS 12.34). Due to the potentially great uncertainty and the closely associated fundamental doubts about the recoverability of deferred taxes on loss carryforwards, the required fulfillment of the 'more-likely-than-not' criterion (probability of exposure $>50$ percent) is barely enough to refute the stopping of the loss history (Hoffmann, 2012, marginal no. 56).

Instead of accordingly imposing higher requirements for recognition in the balance sheet, it is now advocated that financial reporting first independently inform about the recoverability of all deferred taxes on loss carryforwards with a probability of realization greater than zero percent (Chludek and Tran, 2012, p. 5). In accordance to IAS $12.81(\mathrm{e})$, only loss carryforwards, not taken into account the generation of deferred taxes, have been stated and not the associated (implausible) tax relief. This excluded a direct comparison with capitalized (plausible) tax relief (Chludek and Tran, 2012, p. 6). Only in a second step shall a reduction of a 'valuation allowance' in the amount of the non-recoverable deferred tax assets on loss carryforwards take place, however, for this purpose, the under-usage of the (fully subjective) 50-percent probability of exposure shall be relevant (Chludek and Tran, 2012, p. 5). ${ }^{1}$

Applying this 'gross information method' shall, ceteris paribus, not change the balance sheet valuation compared to the previously used 'net information method' (Chludek and Tran, 2012, p. 5). Information is, however, provided as to what proportion of the possible tax advantage can actually be used (Chludek and Tran, 2012, p. 6.). This, in turn, also establishes transparency for the likely unusable loss carryforwards and allows for the external determination of a 'realization coefficient' (Chludek and Tran, 2012, p. 8).

In this way, however, along the lines of 'quantity instead of quality of information', basically only 'hopeless' values (probability $\leq$ 50 percent) are reported aside from 'hopeful' values (probably > 50 percent). This approach may, nonetheless, seem informative at first glance, as the recipient even receives information about the amount of the likely unusable tax advantages of the loss carryforwards. It should be recognized that an (open) self-evaluation of future profitability or the company's long-term viability is delivered by the management. Such private information could, however, explain the value relevance of this 'empty balance sheet item' (see Kumar and Visvanathan, 2003, p. 488). Private information is either accounted for by the market or it meets and confirms market expectations. Whoever demands for the disclosure for unusable tax advantages disregards the fact that this could create an even greater incentive to use the existing potential of an overvaluation in the context of the capitalization of deferred taxes from loss carryforwards (see Kumar and Visvanathan, 2003, pp. 471-90). This leads to the dilemma discussed below: Is the valuation allowance and the associated disclosure of private information crucial? Can the disclosure not

\footnotetext{
${ }^{1}$ IASB (2009, Appendix A) defines valuation allowance as 'The amount recognised against deferred tax assets so that the net amount equals the highest amount that is more likely than not to be realisable against taxable profit.'
} 
be trusted? After all, actually noncapitalizable deferred taxes from loss carryforwards can be capitalized to avoid negative reactions of the recipients.

\section{The Risk Potential of Deferred Tax Assets on Loss Carryforwards}

The capitalization of deferred taxes on loss carryforwards becomes an increasingly important issue especially in periods of losses in two ways. On the one hand, loss carryforwards can accumulate through losses in the tax balance sheet over a specific period of time. On the other hand, through the utilization of the possibility of capitalization of the associated deferred taxes for investors can lead to a palliated IFRS result. At the same time, the uncertainty regarding the usability of the loss carryforwards continues to increase during an ongoing period of (tax) losses, as a trend reversal, which is, because of the duration of the period of losses, rather unlikely, would have to move towards a sustainable period of (tax) profits. If the responsible management does not include existing loss carryforwards in the tax deferral, it acknowledges that it will fail to realize any taxable profits in the near future (Schulze-Osterloh, 2008, p.68). To avoid such negative signals a 'generous' capitalization would have to occur, ultimately running the risk of the disclosure of 'extraordinarily uncertain assets items' (overvaluation), which could lead to an 'additional need of depreciation because the realization of the tax assets has become implausible, resulting in the accumulation of the negative developments' (SchulzeOsterloh, 2008, p. 68).

A sufficient probability for the usability of loss carryforwards can only, in the case of a history of continuous loss, be found with a prefaced strategy change, new business models or restructuring (a necessary, albeit insufficient condition) (Hoffmann and Lüdenbach, 2012, marginal no. 38; Berger, 2006, p. 2474). Internal tax planning is, therefore, crucial. The internal tax planning will, in case of doubt, however only echo the decision maker's (calculated) optimism necessary to continue business, because it would not evidence a failure (of a third party or itself) due to too-realistic tax planning (Brösel, Haaker and Zwirner, marginal no. 106). Since a (tax) loss in the past financial year necessarily indicates depreciation of deferred tax assets from loss carryforwards and, at the same time, is also the reason for a value increase of the tax deferral (Schildbach, 1998, p. 945), it implies the following:

The Higher the 'House of Cards' of Deferred Tax Assets from Loss Carryforwards Becomes Over Time, the More Probable Its Collapse!

Besides the potential for deception of others, the already suggested risk of a self-deception can play a role in the proximity of a crisis (Thaler and Sunstein, 2009, p. 34 et seq.). This is why there may be a distorted net effect between the impairment requirement due to occurring losses and the increasing potential of capitalization from loss carryforwards according to the signs (Schildbach, 1998, p.945), but it is more likely due to 'overoptimism'. In short: the 'house of cards effect' reinforces itself! If not even the 'more likely than not' principle is followed, one can only agree with Schildbach's view. As he explains (Schildbach, 1998, p. 945):

Negative risk management is done with the capitalization of deferred taxes from carryforward losses. As long as the future prospects of a company are considered to be positive, deferred tax assets reduce the charges from the losses. Once the situation reaches a critical stage, the required depreciation of the as-yet deferred tax assets will be added to the newly incurred losses. Deferred tax assets can become so burdensome in a crisis that they can destroy the threatened company. 
Corresponding unfavorable developments can be tellingly found in the case of General Motors and many others (see Giersberg, 2008). In the current debate, the risk of procyclicality (Küting, Pfitzer and Weber, 2011, p. 200) needs to be emphasized, especially since major American banks seem to be accumulating deferred tax assets in a threatening way (The Economist, 2011; Haaker, 2012b, p. 23). For this reason, Professor Hennrichs calls deferred taxes from carryforward losses 'fire accelerators' (Deutscher Bundestag, 2008, p. 3).
For Instance: A company generates at a tax rate of 30 percent an annual loss of 100 monetary units (MUs) over a period of three years ( $t=1,2$ and 3 ) and capitalizes the expected tax benefits from loss carryforwards. Due to a global recession, the loss increases to 200 MUs which does no longer justify the value of the deferred tax assets in the fourth year ( $t$ = 4). Therefore, especially the tightening of a crisis situation can result in an additional depreciation in the amount of the deferred tax assets:

Table 1: Additional Depreciation of Deferred Tax Assets

\begin{tabular}{|l|c|c|c|c|}
\hline & $\mathbf{t = 1}$ & $\mathbf{t = 2}$ & $\mathbf{t = 3}$ & $\mathbf{t = 4}$ \\
\hline $\begin{array}{l}\text { Profit/loss } \\
\text { before } \\
\text { deferred taxes }\end{array}$ & $-100 \mathrm{MUs}$ & $-100 \mathrm{MUs}$ & $-100 \mathrm{MUs}$ & $-200 \mathrm{MUs}$ \\
\hline Tax income & $+30 \mathrm{MUs}$ & $+30 \mathrm{MUs}$ & $+30 \mathrm{MUs}$ & $-90 \mathrm{MUs}$ \\
\hline $\begin{array}{l}\text { Profit/loss } \\
\begin{array}{l}\text { after deferred } \\
\text { taxes }\end{array}\end{array}$ & $-70 \mathrm{MUs}$ & $-70 \mathrm{MUs}$ & $-70 \mathrm{MUs}$ & $-290 \mathrm{MUs}$ \\
\hline
\end{tabular}

A comparable situation can be found in the case of General Motors: Suddenly accumulated deferred tax assets of 38,6 billion dollars had to be depreciated (see Giersberg, 2008).

Against this background, deferred tax assets from loss carryforwards can hardly be useful information for external consultants, as the standard setters would lead us to believe (Schildbach, 1998, p. 945).2 They tend to appear during loss-making situations, when there is an intensified incentive to take advantage of the creative potential of such insecurity. This threatening trend could even increase with the disclosure of a valuation allowance regarding deferred tax assets from loss carryforwards.

\footnotetext{
2 In contrast, recent literature mentions an information advantage regarding the signal of a potential tax reduction. See Williams, 1966, p. 231 and Ordelheide, 1995, p. 603.
}

Reinforced False Incentives through the Disclosure of a Valuation Allowance Regarding Deferred Tax Assets from Loss Carryforwards

Until now, there has been an incentive to consider dubious loss carryforwards in the capitalization of deferred tax assets, at least insofar as the disclosure of a loss should be avoided or an expected capital market result achieved. Thus, the disclosure of a valuation allowance will reinforce the incentive to 'capitalize in all circumstances'. It has thus far sufficed, in certain cases, to cover losses or achieve the expected profits to draw only partially from the loss carryforwards. There is, due to the additional information regarding the likely unusable loss carryforwards, even the incentive to set up deferred tax assets for all loss carryforwards. This can be done even if the usability is highly in doubt and the earning targets would be achieved even without a progressive capitalization. 
5 Journal of Accounting and Auditing: Research \& Practice

Should the realization coefficient as a ratio index between the capitalized and noncapitalized deferred taxes from loss carryforwards become the focus of the recipients, the management would face negative reactions in the case of a tooconservative integration of the existing potential of a tax reduction. This is because the ratio provides information about the future potential of profits. In order to avoid a 'backlash', the management could be forced to extensively capitalize deferred taxes from loss carryforwards.

For Instance: In the current business year, a company loses 10 monetary units (MUs) before the capitalization of deferred taxes from loss carryforwards in the tax balance sheet and the IFRS financial statement. In past business years, loss carryforwards of 140 MUs have been collected. These have yet to be utilized as capitalized deferred taxes. The tax rate amounts to 30 percent. According to a conservative estimate, only for loss carryforwards of 50 MUs does a sufficient probability of use in the near future exist.

In order to avoid a loss or the disclosure of a profit of 5 MUs (= [-10]+[50x0.3]), it would suffice to take only the likely usable loss carryforwards of $15 \mathrm{MUs}$ (=50x0.3) into account for the deferral on tax. Should the valuation allowance be disclosed, the recipients would nevertheless be informed that the tax advantages of the loss carryforwards of 30 MUs $(=[140+10-50] \times 0.3)$ cannot, according to the company's (self-) evaluation, be used. These potentials, unrecoverable and stigmatized due to non-capitalization, can be contrasted with the tax advantages of 15 MUs $(=50 \times 0.3)$, attainable and anticipated in light of the accomplished capitalization, resulting in a realization coefficient of $1 / 2$ or a realization ratio of $1 / 3$ (33.3 percent):

$\operatorname{Re}$ alization coefficien $t=\frac{\text { capitalize } d \text { deferred taxes from loss carryforwa } r d s}{n o n-\text { capitalize d deferred taxes from loss carryforwa } r d s}=\frac{15}{30}=\frac{1}{2}=0.5$

Re alization ratio $=\frac{\text { capitalize d deferred taxes from loss carryforwa } r d s}{\text { total of deferred taxes from loss carryforwa } r d s}=\frac{15}{45}=\frac{1}{3}=33.3 \%$

Since only 33.3 percent of the tax advantages from loss carryforwards due to the capitalization are classified as usable, the recipients should have serious concerns about the ability of the company to achieve future profits despite a profit disclosure of 5 MUs (which could meet the expectations of the capital market). It, therefore, makes sense to assume that the management responsible for reporting by means of the IFRS financial statement must anticipate such 'concerns' and reconsider its 'tentative' estimations of the probability of realization. As far as it is 'practicable', the probability assumptions could be reconsidered in order to achieve a realization ratio of at least 50 percent. Cases can certainly arise, in which a realization ratio of 75 percent or even 100 percent towards can be enforced by the auditor to prevent 'unsettling' the recipients, whereas a capitalization of 15 MUs (realization ratio $=33.3$ percent) would have sufficed in achieving a profit target. As described in Section 3, the depreciation potential accumulates with the capitalization, and the probability also increases with the visibly improved realization ratio, so that, over time, 'deferred tax assets become a millstone around the neck of the threatened business, ultimately pulling it down into the abyss' (Schildbach, 1998, p. 945). The 'millstone', which has so far consisted of rather likely usable loss carryforwards, reinforces the burden of the rather implausible loss carryforwards because of the disclosure of the valuation allowance.

How pronounced such a theoretically assumed misguided incentive of a progressive capitalization of deferred taxes from loss carryforwards would actually be, can be regarded as an empirical question 
(e.g. Kumar and Visvanathan, 2003, pp. 47190), which might also be related to the implementation and enforceability of financial reporting. These requirements seem to be particularly afflicted with certain problems in the field of deferred tax assets from loss carryforwards (Berger, 2006, pp. 2473-2475). Overall, it should be a cause for alarm that it is no longer merely anticipated values, but also increasingly dubious ('hopeless') ones that will be capitalized as supposed tax benefits.

\section{Conclusions}

For reasons of transparency, recent literature strongly advocates the introduction of a socalled valuation allowance for deferred tax assets from loss carryforwards (Chludek/Tran, 2012, p. 4; see for the corresponding IASB-Proposal IASB, 2009, marginal no. 23 and B14-B25). In doing so, the full amount of deferred tax claims would initially have to be taken into consideration, and an allowance of the likely unusable amount has to then be carried out, which is to be made transparent at least in the notes. The possible information advantages concerning the expected profit or loss developments of the reporting company must be compared with the associated potential misguided incentives for an extensive capitalization of deferred taxes from loss carryforwards, which would foster not only the accumulation of the dangerous depreciation potential, but the initially assumed information advantage would also be lost, because the probability of use of capitalized deferred taxes from loss carryforwards would be (even) less clear. The disclosure of solely anticipated values is already questionable, which is why yet another incentive for the capitalization of dubious (rather 'hopeless') values by financial reporting standards should not necessarily be put in place.

\section{References}

Berger, A. (2006). 'Was der DPR Aufgefallen Ist: Ermessensspielraum und die Bilanzierung von latenten Steuern auf Verlustvorträge,' Der Betrieb, 60 (46), 24732475.

Brösel, G., Haaker, A. \& Zwirner, C. (2012). '§ 274 HGB (Latente Steuern), Bonner Handbuch Rechnungslegung,' 2nd Edition, Grewe, W. et al. (eds.), Köln (forthcoming as supplement delivery).

Chludek, A. \& Tran, D. H. (2012). "Der Reformvorschlag des IAS 12 gem. ED/2009/2 - Ein Plädoyer Für Die Einführung der Valuation Allowance," Zeitschrift Für Internationale und Kapitalmarktorientierte Rechnungslegung, 12 (1), 4-8.

Christensen, T. E., Paik, G. H. \& Stice, E. K. (2008). "Creating a Bigger Bath Using the Deferred Tax Valuation Allowance," Journal of Business Finance \& Accounting, 35 (5-6), 601-625.

Deutscher Bundestag (2008). Öffentlichen Anhörung im Rechtsausschuss zum Entwurf eines Gesetzes zur Modernisierung des Bilanzrechts

(Bilanzrechtsmodernisierungsgesetz - BilMoG) vom 17.12.2008, BT-Protokoll Nr. 122, Berlin.

Economist (2012). "Double-edged Deferral How Lower Taxes Could Hurt America's Big Banks," The Economist, 401 (8763), 74-75.

Giersberg, G. (2008). "Der Milliardenpoker Um Die Latenten Steuern," [Online], Frankfurter Allgemeine Zeitung, [Retrieved April 11, 2008], http://www.faz.net/aktuell/wirtschaft/recht -steuern/unterm-strich-die-neue-bilanzweltder-milliardenpoker-um-die-latentensteuern-1537033.html. 
7 Journal of Accounting and Auditing: Research \& Practice

Haaker, A. (2012a). "Verstärkt der Ausweis Einer Valuation Allowance den Fehlanreiz zur Progressiven Aktivierung von Latenten Steuern Auf Verlustvorträge?," Zeitschrift Für Internationale und Kapitalmarktorientierte Rechnungslegung, 12 (6), 265-268.

Haaker, A. (2012b). "Anreizverträgliche Aktivierung Von Latenten Steuern Auf Verlustvorträge? (Contra)," Praxis der Internationalen Rechnungslegung, 8 (1), 23.

Hoffmann, W.- D. (2012). 'Steuern vom Einkommen (§ 26), IFRS-Kommentar,' 10th Edition, Lüdenbach, N. and Hoffmann, W.-D., Freiburg et al.

Hoffmann, W.- D. \& Lüdenbach, N. (2012). NWB Kommentar Bilanzierung, 3rd. Edition, Herne.

IASB (2009). Exposure Draft ED/2009/2: Income Tax, London.

Kumar, K. R. \& Visvanathan, G. (2003). "The Information Content of the Deferred Tax Valuation Allowance," The Accounting Review, 78 (2), 471-490.

Küting, K., Pfitzer, N. \& Weber, C.- P. (2011). IFRS oder HGB? - Systemvergleich und Beurteilung, Stuttgart.

Ordelheide, D. (1995). 'Aktivische Latente Steuern bei Verlustvorträgen im Einzel- und Konzernabschluss - HGB, SFAS und IAS,' Internationale Wirtschaftsprüfung, Festschrift für H. Havermann, Lanfermann, J. (ed.), Düsseldorf, 601-623.

Schildbach, T. (1998). 'Latente Steuern Auf Permanente Differenzen und Andere Kuriositäten - Ein Blick in das Gelobte Land Jenseits der Maßgeblichkeit,' Die Wirtschaftsprüfung, 51 (21), 939-947.

Schulze-Osterloh, J. (2008). 'Ausgewählte Änderungen des Jahresabschlusses Nach dem Referentenentwurf Eines Bilanzrechtsmodernisierungsgesetzes,' Deutsches Steuerrecht, 46 (1/2), 63-73.
Thaler, R. H. \& Sunstein, C. R. (2009). Nudge: Improving Decisions about Health, Wealth and Happiness, London.

Williams, D. Z. (1966). "Reporting Loss Carryovers in Financial Statements," The Accounting Review, 41 (2), 226-234. 